\title{
Identifikasi Potensi Pelanggaran Kawasan Konservasi Pantai Timur Surabaya Berdasarkan Pemodelan Spasial Prediksi Tren Perkembangan Penggunaan Lahan Berbasis Cellular Automata
}

\author{
Lukman Yusuf dan Cahyono Susetyo \\ Departemen Perencanaan Wilayah dan Kota, Fakultas Arsitektur Desain dan Perencanaan \\ Institut Teknologi Sepuluh Nopember (ITS) \\ Jl. Arief Rahman Hakim, Surabaya 60111 Indonesia \\ e-mail: cahyono_s@urplan.its.ac.id
}

\begin{abstract}
Abstrak-Keterbatasan lahan di Surabaya membuat kawasan Pantai Timur Surabaya (Pamurbaya) dilirik oleh pihak pengembang permukiman swasta. Namun, RTRW Kota Surabaya 2014 menetapkan kawasan Pamurbaya sebagai kawasan lindung/konservasi dengan zona ruang terbuka hijau. Dari seluruh kawasan konservasi Pamurbaya 92,66\% masih berstatus kepemilikan perorangan. Sehingga terjadi kerawanan pelanggaran pada kawasan konservasi Pamurbaya. Dari perhitungan GIS faktual lapangan 2017, sudah terjadi pelanggaran sebesar $0,5 \%$ dari seluruh kawasan konservasi Pamurbaya. Selain itu kerawanan ini di perkuat dengan kondisi tutupan lahan saat ini, dari seluruh kawasan konservasi seluas 2.503,9 Ha, didominasi tutupan lahan tambak seluas 2080,40 Ha.

Sehingga dalam penelitian ini bertujuan untuk mengidentifakasi potensi pelanggaran pada kawasan konservasi Pamurbaya berdasarkan model spasial prediksi tren perkembangan lahan tahun 2034. Hasil penelitiannya adalah faktor yang dominan mempengaruhi perkembangan lahan di Pamurbaya adalah faktor adanya jaringan jalan lingkar luar timur Surabaya dan kedekatan dengan permukiman yang sudah ada. Pola perkembangan lahan eksisting di kawasan Pamurbaya selama 2011-2017 didominasi dengan pertumbuhan permukiman sebesar 602,35 Ha, dan tambak tumbuh sebesar 222,45 Ha. Kemudian berdasarkan prediksi tren perkembangan lahan Pamurbaya tahun 2034 dengan Cellular Automata, diprediksi permukiman akan tumbuh sebesar $62 \%$ dari luas saat ini, industri akan tumbuh sebesar $7 \%$, perdagangan jasa akan tumbuh $15 \%$. Juga diprediksi tambak akan berkurang 29\% dari luas saat ini. Indetifikasi potensi pelanggaran kawasan konservasi Pamurbaya menghasilkan pada tahun 2029 kawasan konnservasi diprediksi akan terjadi pelanggaran $8,74 \%$ dan tahun 2034 akan terlanggar $24,02 \%$.
\end{abstract}

Kata Kunci- Potensi Pelanggaran; Pemodelan Penggunaan Lahan ; Cellular Automata

\section{PENDAHULUAN}

K OTA Surabaya merupakan kota terbesar kedua di Indonesia. Kemajuan Surabaya mendorong peningkatan kegiatan perkotaan yang menyebabkan kebutuhan akan lahan yang semakin meningkat padahal ketersediaannya sangatlah terbatas (Pradiptiyas, 2011).

Kondisi saat ini, wilayah Surabaya yang masih memiliki lahan yang luas untuk dibangun adalah Surabaya Timur, tepatnya Pantai Timur Surabaya. Sehingga wilayah ini dilirik pihak swasta untuk dibangun kawasan permukiman. Selain itu, faktor lain yang membuat pihak pengembang tertarik pada kawasan ini adalah adanya infrastruktur vital yang menjadikan daerah ini semakin strategis. Pantai Timur Surabaya (Pamurbaya) memiliki luas wilayah 2.503,9 Ha. Kawasan ini terbagi menjadi 4 wilayah Kecamatan yaitu Gunung Anyar, Mulyorejo, Sukolilo dan Rungkut.

RTRW Kota Surabaya 2014-2034 menetapkan kawasan Pamurbaya sebagai kawasan lindung/konservasi dengan zona ruang terbuka hijau. Pertimbangannya adalah pada Pamurbaya memiliki hutan mangrove yang berfungsi sebagai perlindungan bawahan.

Permasalahannya adalah status tanah di kawasan Pamurbaya yang masih banyak dimiliki oleh pihak perorangan. Sehingga masih ditemukan adanya masyarakat yang melakukan jual beli lahan kepada pengembang, padahal sudah jelas bahwa sebagai kawasan konservasi maka tidak diizinkan untuk dibangun. Akan tetapi, sebagai pemilik lahan yang membayar pajak setiap tahunnya, maka pemilik lahan akan cenderung mengupayakan agar lahannya menghasilkan nilai ekonomi, sehingga apabila dilarang untuk dibangun maka akan sangat merugikan pemilik lahan.

Data Dinas Pengelolaan Bangunan dan Tanah Kota Surabaya Terkait Penguasaan Tanah Aset Pemerintah Kota Surabaya di Kawasan Pamurbaya 2016 menyatakan dari seluruh wilayah konsevasi di Pamurbaya yang luasnya adalah 25.610.342,01 $\mathrm{m}^{2}$ hanya $1.881 .165 \mathrm{~m}^{2}$ yang merupakan aset Pemerintah Kota Surabaya, jika dipresentasekan tanah aset milik Pemkot Surabaya ada hanya $7,34 \%$ dan milik perorangannnya 92,66\%. Dari masalah tersebut muncul fenomena yang terjadi saat ini yaitu rawannnya pelanggaran yang terjadi di kawasan konservasi Pamurbaya.

Kerawanan ini diperkuat oleh pada kondisi eksisting 2018 yang sudah terjadi pelanggaran di kawasan konservasi Pamurbaya. Dengan menggunakan metode GIS membandingkan antara area konservasi dengan citra satelit 2017 diketahui ada 2 lokasi yang sudah terjadi pelanggaran. Pertama pada koordinat $07^{\circ} 20^{\prime} 05.38214^{\prime}$ 'S dan $112^{\circ} 49^{\prime}$ 05.30508 " E terjadi pelanggaran seluas $9.94 \mathrm{Ha}$. Kedua pada koordinat $07^{0} 19$ ' 31.73873 " $\mathrm{S}$ dan $112^{\circ} 48^{\prime} 34.33915$ " E terjadi pelanggaran seluas $3.77 \mathrm{Ha}$.

Selain disebabkan oleh status lahan, kerawanan pelanggaran di kawasan konservasi Pamurbaya disebabkan karena pertimbangan menetapkan Pamurbaya yang masih 
diragukan. Pada RTRW Kota Surabaya 2014-2034, penetapannya didasarkan akan adanya ekosistem mangrove harus dilindungi. Akan tetapi fakta eksisting lapangan saat ini dari 2.503,9 Ha yang memiliki tutupan lahan mangrove hanya 427,64 Ha, sangat jauh timpang dengan luas tambak di kawasan konservasi seluas 2080,40 Ha.

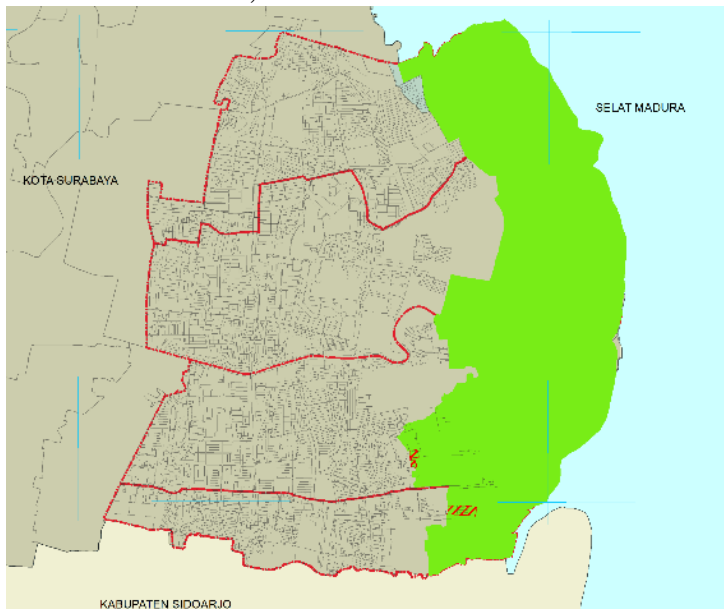

Gambar 1. Orientasi Wilayah Penelitian

\section{METODE PENELITIAN}

\section{A. Tujuan Penelitian}

Tujuan dari penelitian ini adalah mengidentifikasi potensi pelanggaran kawasan konservasi Pantai Timur Surabaya berdasarkan pemodelan spasial prediksi tren perkembangan penggunaan lahan tahun 2034.

\section{B. Jenis dan Pendekatan Penelitian}

Penelitian ini menggunakan pendekatan kuantitatif dikarenakan analisis yang dilakukan untuk mencapai sasaran dan tujuan dengan pengolahan data-data numerik. Faktor hasil kajian teori akan dibobotkan dengan preferensi stakeholders untuk mengetahui bobot faktor yang mempengaruhi perkembangan penggunaan lahan Pamurbaya, selanjutnya data sekunder penggunaan dari dua waktu yang berbeda dikomparasikan untuk mengetahui tren pola perkembangan lahan setiap tahunnya. Selanjutnya adalah memodelkan spasial prediksi tren. Terakhir adalah dengan mengidentifikasi potensi pelanggaran kawasan konservasi Pamurbaya pada tahun 2034.

\section{Aspek dan Faktor Penelitian}

Aspek dan faktor dalam penelitian ini digunakan untuk mengindentifikasi faktor-faktor yang mempengaruhi perkembangan penggunaan lahan di Pamurbaya.

Tabel 1.

Aspek dan Faktor Penelitian

\begin{tabular}{ll}
\hline \hline ASPEK & FAKTOR \\
\hline \multirow{3}{*}{$\begin{array}{l}\text { Kondisi Fisik dan } \\
\text { Lingkungan }\end{array}$} & Jarak dari Daerah Bencana \\
\cline { 2 - 2 } & Jarak dari Kegiatan Industri \\
\hline \multirow{3}{*}{$\begin{array}{l}\text { Dukungan terhadap } \\
\text { Sarana Kawasan }\end{array}$} & Fasilitas Perdagangan \\
\cline { 2 - 2 } & Fasilitas Pendidikan \\
\cline { 2 - 2 } & Fasilitas Perkantonan \\
\hline
\end{tabular}

\begin{tabular}{|c|c|}
\hline \multirow[t]{3}{*}{ ASPEK } & FAKTOR \\
\hline & Fasilitas Peribadatan \\
\hline & Fasilitas Persampahan \\
\hline \multirow{8}{*}{$\begin{array}{l}\text { Dukungan terhadap } \\
\text { Prasarana Kawasan }\end{array}$} & Rencana Jaringan Lingkar Luar Surabaya \\
\hline & Jaringan Listrik \\
\hline & Jaringan Telepon \\
\hline & Jaringan Air Bersih \\
\hline & Jaringan Drainase \\
\hline & Jaringan Sungai \\
\hline & Jaringan Jalan Utama \\
\hline & Jaringan Jalan Lingkungan \\
\hline \multirow{6}{*}{$\begin{array}{l}\text { Kondisi Fisik dan } \\
\text { Lingkungan }\end{array}$} & Jarak dari Daerah Bencana \\
\hline & Jarak dari Daerah Pesisir \\
\hline & Jarak dari Sungai/Muara \\
\hline & Jarak dari Tambak Eksisting \\
\hline & Jarak dari Area Mangrove \\
\hline & Jarak dari Area Permukiman \\
\hline \multirow{3}{*}{$\begin{array}{l}\text { Dukungan terhadap } \\
\text { Prasarana Kawasan }\end{array}$} & Rencana Jaringan Jalan Lingkar Luar \\
\hline & Jaringan Jalan Utama \\
\hline & Jaringan Jalan Lingkungan \\
\hline
\end{tabular}

\section{Populasi dan Sampel}

Populasi dalam penelitian ini adalah luas seluruh wilayah Pantai Timur Surabaya. Sedangkan sampel dalam penelitian ini digunakan untuk menentukan validasi hasil ekstrak citra lidar untuk memperoleh data penggunaan lahan yang sesuai dengan realitas di lapangan.

Pengambilan sampel dalam penelitian ini dilakukan secara acak menggunakan spatial random sampling. Prosedur sampling acak secara spasial dipilih sesuai dengan kebutuhan penelitian untuk menilai akurasi peta penggunaan lahan paling aktual. Pengambilan spasial sampling dalam penelitian ini terdapat 100 titik lokasi secara random lokasi dan jenis penggunaan lahannya. Penempatan titik sampel memiliki rentang jarak yang variatif satu sama lain yang ditentukan secara spasial (random point-based sampling schemes). Sampel yang digunakan ini nantinya akan dihitung untuk persentase akurasi peta penggunaan lahan.

\section{E. Metode Analisis}

1) Menentukan faktor-faktor yang mempengaruhi perkembangan penggunaan lahan Pamurbaya

Untuk menyusun model prediksi tren perkembangan lahan Pamurbaya maka diperlukan faktor-faktor yang mempengaruhi perkembangannya berserta dengan bobot faktornya. Hal tersebut diperlukan untuk menyusun peta transisi setiap penggunaan lahan yang di prediksi. Untuk mencapai tujuan tersebut maka akan melalui tahap sebagai berikut 1.Menentukan faktor-faktor yang mempengaruhi perkembangan masing-masing penggunaan lahan 2.Menentukan stakeholders yang akan dijadikan responden 3.Menghitung bobot setiap faktor yang mempengaruhi perkembangan setiap penggunaan lahan dengan menggunakan teknik AHP.

Tabel 2.

Tingkat Kepentingan dalan analisis AHP

\begin{tabular}{ll}
\hline NILAI & KETERANGAN \\
\hline 1 & Kedua elemen sama pentingnya \\
\hline 3 & Elemen yang satu sedikit lebih penting daripada elemen lainnya \\
\hline 5 & Elemen yang satu lebih penting daripada elemen lainnya \\
\hline
\end{tabular}




\begin{tabular}{ll}
\hline 7 & Satu elemen lebih mutlak penting dari elemen lainnya \\
\hline 9 & Satu elemen mutlak penting daripada elemen lainnya \\
\hline $2,4,6,8$ & Nilai-nilai antara dua nilai pertimbangan yang berdekatan \\
\hline
\end{tabular}

\section{2) Mengidentifkasi tren pola perkembangan penggunaan lahan Pamurbaya}

Untuk menyusun model spasial prediksi tren perkembangan penggunaan lahan masa depan Pamurbaya, diperlukan informasi tren pola perkembangan lahan eksisting. Informasi tren pola perkembangan lahan eksisting yang dibutuhkan mencakup :

- Penggunaan lahan yang aktif mengkonversi penggunaan lahan lain.

- Luas konversi penggunaan lahan satu dengan yang lainnya.

- Lokasi penggunaan lahan yang berubah.

- Matriks perubahan penggunaan lahan.

Untuk mencapainya, berikut tahapan dalan analisis ini.

a) Persiapan data dilakukan dengan mengiventarisasi data yang dibutuhkan dalam tahap ini

b) Klasifikasi penggunaan lahan 2017

c) Validasi Penggunaan Lahan 2017

d) Overlay penggunaan lahan 2011 dan 2017
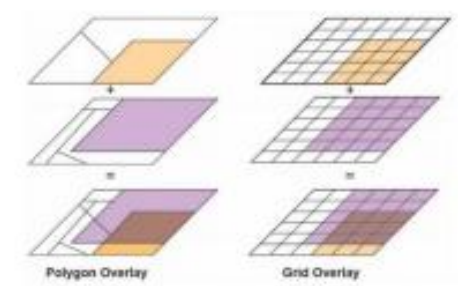

Gambar 2. Ilustrasi Teknik Overlay pada GIS

3) Melakukan pemodelan spasial prediksi tren perkembangan lahan masa depan Pamurbaya tahun 2034

Pada tahap ini akan dilakukan permodelan perubahan lahan melalui Cellular Autamata. Dalam penelitian ini akan digunakan software LanduseSim yang dikembangkan oleh (Pratomoatmojo, 2014) yang memiliki kemampuan untuk mensimulasikan multilanduse hingga maksimal 40 unit landuse yang tumbuh secara bersamaan. Dalam tahap ini berikut langkahlangkahnya.

1) Penentuan bobot faktor-faktor yang mempengaruhi perkembangan penggunaan lahan di Pamurbaya

2) Analisis spasialisasi faktor penentu perkembangan lahan

3) Penyusunan peta transisi/ suitability of landuse

4) Membentuk neighborhood filter

5) Menentukan transition rules

6) Melakukan simulasi LUCC CA

7) Validasi model simulasi

\section{4) Mengidentifikasi Potensi Pelanggaran Kawasan Konservasi Pamurbaya tahun 2034}

Identifikasi potensi pelanggaran kawasan konservasi didasarkan pada model spasial prediksi tren perkembangan penggunaan lahannya. Teknik yang akan digunakan adalah komparasi antara data vector kawasan konservasi dengan model spasial prediksi tren perkembangan penggunaan lahannya dimasa depan. Proses komparasi akan dibantu dengan metode intersect overlay dengan software Arc Map. Komparasi akan dilakukan dalam 4 iterasi yaitu pada tahun 2019, 2024, 2029 dan 2024. Hasilnya adalah presentasekan untuk menunjukan potensi pelanggaran kawasan konservasi oleh penggunaan lahan tertentu.

\section{HASIL DAN PEMBAHASAN}

\section{A. Menentukan Faktor-Faktor yang Mempengaruhi Perkembangan Penggunaan Lahan Pamurbaya}

Langkah yang digunakan dalam tahap ini yang pertama adalah analisis stakeholders. Analisis ini dilakukan untuk menentukan stakeholders yang memiliki peran dan ahli dalam bidang pengelolaan tata guna lahan di Pamurbaya. Setelah dilakukan analisis didapatkan 6 stakeholder yang dapat dijadikan responden dalam pemberian bobot pada variabel penelitian. Stakeholders yang terpilih adalah Badan Perencanaan dan Pembengunan Kota Surabaya, Dinas Perumahan Rakyat dan Kawasan Permukiman, Cipta Karya dan Tata Ruang, Kelompok Pengelola Information Mangrove Center Surabaya, Kelompok Pengelola Ekowisata Mangrove Wonorejo, Ahli Tata Guna Lahan Perkotaan dan Ahli Perencanaan Kawasan Pesisir. Kemudian dilakukan suvey terhadap responden tersebut.

Langkah selanjutnya adalah pembobotan dengan menggunakan teknik AHP (Analysis Hirarkhikal Procces) dengan bantuan software Expert Choice Teknik ini pernah diterapkan oleh (Pratomoatmojo, 2012). Berikut hasil analisis pembobotan yang dihasilkan.

- Bobot faktor yang mempengaruhi perkembangan permukiman

Combined instance - - Synthesis with respect to: Goal: Faktor yang mempengaruhi Permukiman

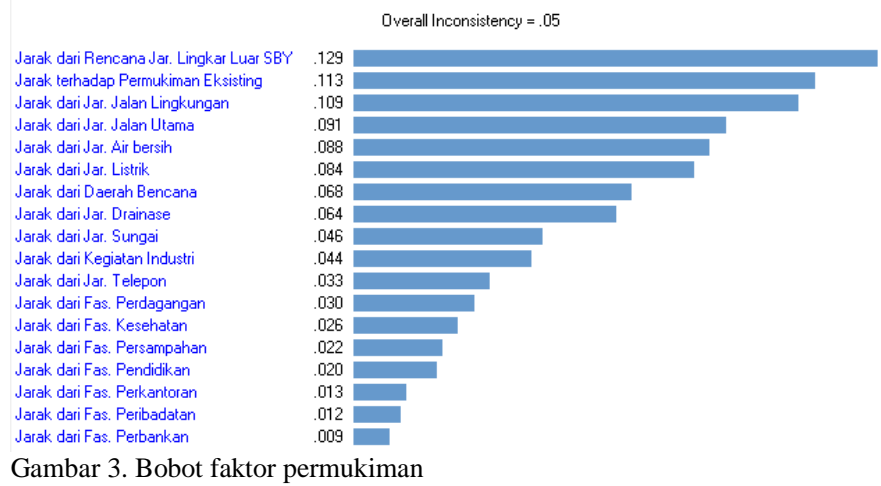

- Bobot faktor yang mempengaruhi perkembangan industry 
Overall Inconsistency $=.06$

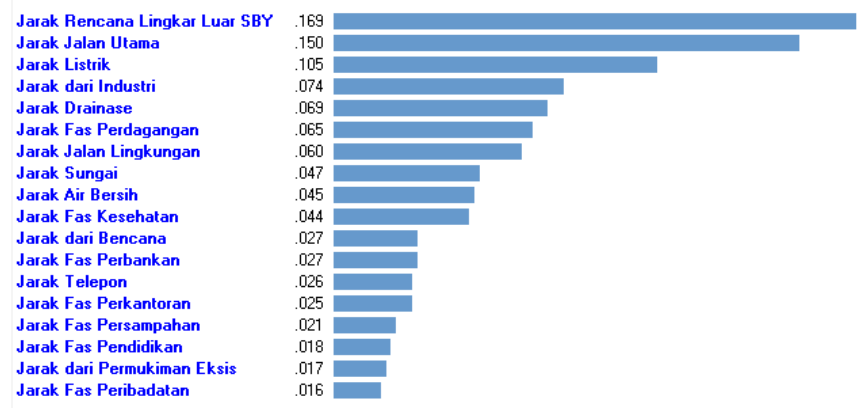

Gambar 3. Bobot faktor industri

- Bobot faktor yang mempengaruhi perkembangan perdagangan dan jasa

Overall Inconsistency $=.08$

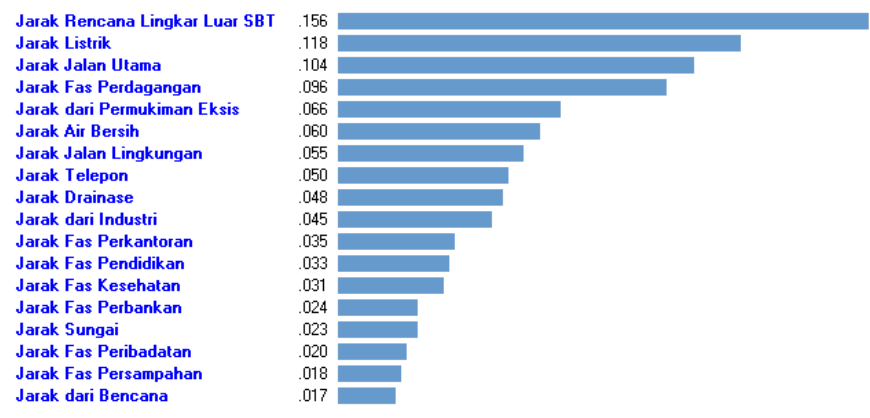

Gambar 4. Bobot faktor perdagangan dan jasa

- Bobot faktor yang mempengaruhi perkembangan tambak

Jarak Tambak Eksis
Jarak Jar Lingkungan
Jarak Jar Utama
Jarak Pesisir
Jarak Sungai
Jarak Mangrove
Jarak Permukiman
Jarak Bencana
Rencana Jar Lingkar Luar SBY

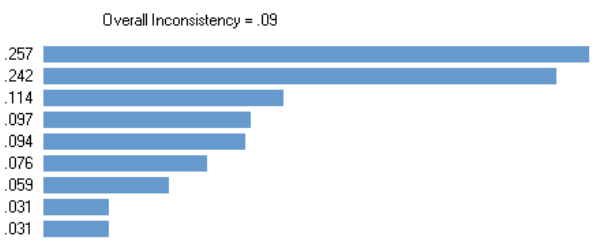

Gambar 5. Bobot faktor tambak

\section{B. Mengidentifkasi Tren Pola Perkembangan Penggunaan Lahan Pamurbaya}

Berdasarkan hasil analisis ini dapat diketahui bahwa selama periode tahun 2011-2017 terjadi perubahan penggunaan lahan seluas 964 hektar. Perubahan ini meliputi penambahan dan pengurangan luasan penggunaan lahan tertentu. Penambahan dialami oleh penggunaan lahan :

- Fasilitas umum $+38,24 \mathrm{Ha}$

- Industri dan Pergudangan $+3,98 \mathrm{Ha}$

- Perdagangan dan Jasa $+11,86 \mathrm{Ha}$

- Permukiman $+602,35 \mathrm{Ha}$

- Tambak $+222,45 \mathrm{Ha}$

Sedangkan penggunaan lahan yang mengalami pengurangan penggunaan lahan adalah

- Hutan Mangrove -224,35 Ha

- Lahan Kosong -193,85 Ha

- Pertanian $-89,12 \mathrm{Ha}$

- Tambak -390,16 Ha
Juga diketahui bahwa pola perubahan penggunaan lahan di Pamurbaya cenderung mengarah ke timur mendekati pesisir laut. Dengan pola perubahan dominan adalah hutan mangrove berubah menjadi tambak, kemudian tambak menjadi permukiman.

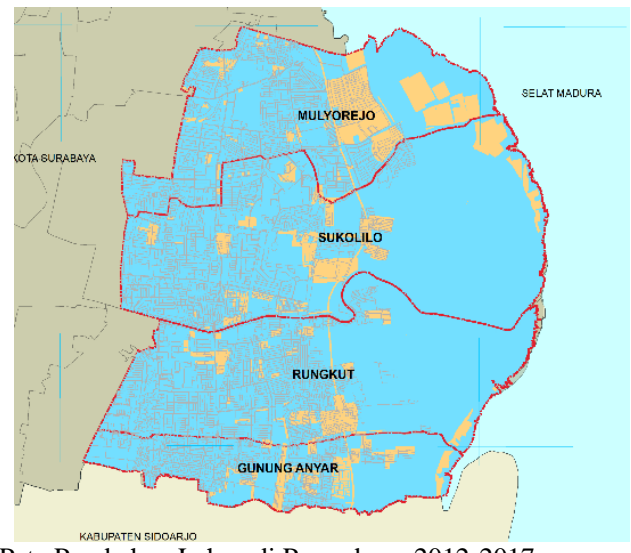

Gambar 6. Peta Perubahan Lahan di Pamurbaya 2012-2017

C. Melakukan Pemodelan Spasial Prediksi Tren Perkembangan Lahan Masa Depan Pamurbaya Tahun 2034

Pemodelan spasial tren perkembangan lahan diawal dengan overlay terhadap peta-peta hasil fuzzy. Adapun overlay dilakukan dengan memasukkan nilai bobot masing-masing faktor yang telah dikonversi nilainya pada rentang $0-1$. Semakin besar nilai bobot yang dimiliki oleh sebuah faktor, maka semakin besar pula faktor tersebut mempengaruhi perkembangan penggunaan lahan. Berikut hasil peta transisi masing masing penggunaan lahan.

- Peta Transisi Permukiman

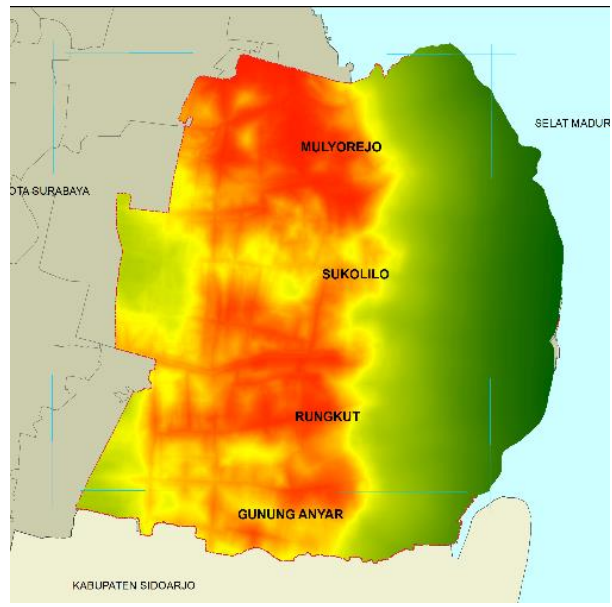

Gambar 7. Peta Transisi Permukiman I 
- Peta Transisi Permukiman

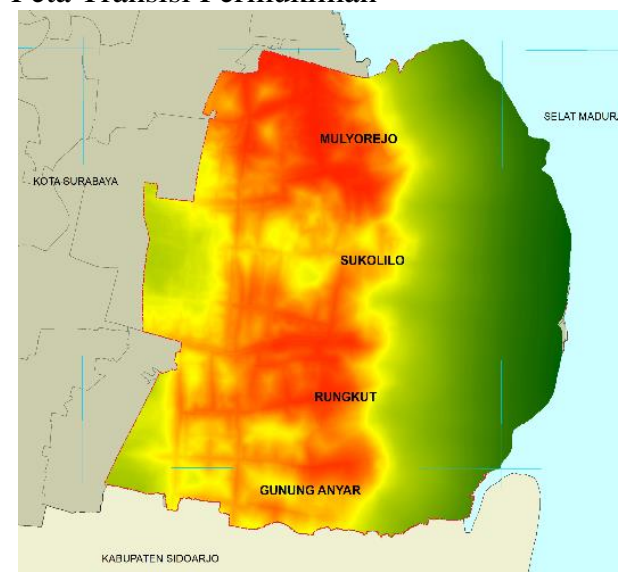

Gambar 8. Peta Transisi Permukiman II

- Peta Transisi Permukiman

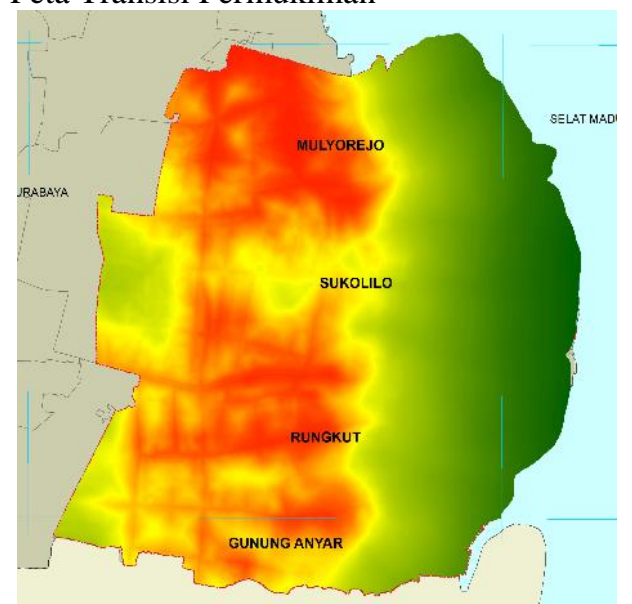

Gambar 9. Peta Transisi Permukiman III

- Peta Transisi Permukiman

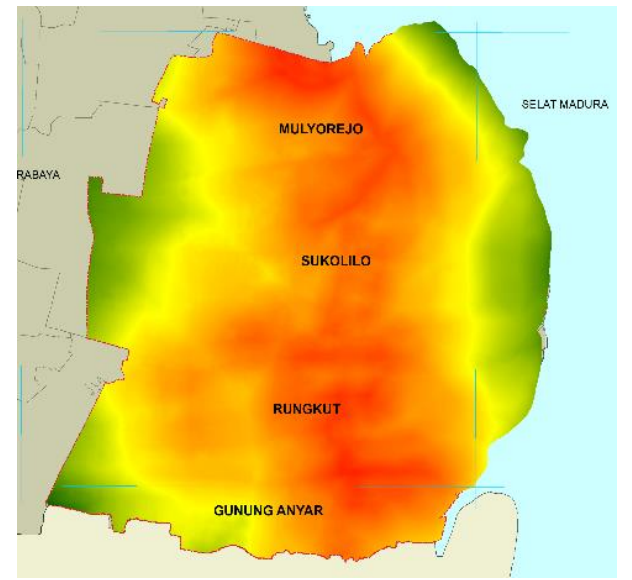

Gambar 10. Peta Transisi Permukiman IV

Langkah selanjutnya adalah menyusun Transition Rules. Transition Rules adalah aturan-aturan yang harus diatur dalam permodelan untuk menentukan perkembangan penggunaan lahan tertentu yang terdiri atas beberapa ketentuan yakni sebagai berikut:

> Kode penggunaan lahan yang dimasukan adalah 4 penggunaan lahan aktif yaitu Industri dan Pergudangan
(2), Perdagangan dan Jasa (7), Permukiman (9) dan Tambak (5).

Urutan landuse yang dimasukkan ke dalam aturan transisi diurutkan berdasarkan landuse yang memiliki kemungkinan untuk terkonversi, sehingga $1^{\text {st }}$ map yang dipilih adalah Industri dan Pergudangan (2), dan selanjutnya Perdagangan dan Jasa (7), Permukiman (9) dan Tambak (5).

$>$ Cell Growth, yakni menunjukkan besar pertumbuhan cell penggunaan lahan aktif yang akan disimulasikan.besaran pertumbuhan cell penggunan lahan didapatkan dari analisis pola perkembangan lahan. Estimasi pertumbuhan dalam meter persegi dikonversi kedalam cellsize $5 \times 5$. Berikut estimasi pertumbuhan 4 penggunaan lahan yang disimulasikan.

Tabel 3.

Cell Growth masing-masing penggunaan lahan

\begin{tabular}{cccc}
\hline NO & $\begin{array}{c}\text { PENGGUNAAN } \\
\text { LAHAN }\end{array}$ & $\begin{array}{c}\text { ESTIMASI } \\
\text { PERTUMBUHAN 2034 } \\
\left(\mathrm{M}^{2}\right)\end{array}$ & $\begin{array}{c}\text { CELL } \\
\text { GROWTH } \\
(\text { CELL })\end{array}$ \\
\hline 1 & Permukiman & 17.066 .670 & 68.2667 \\
\hline 2 & Industri & $112.636,7$ & 4.505 \\
\hline 3 & Perdagangan dan Jasa & $336.090,5$ & 13.444 \\
\hline 4 & Tambak & 6.302 .705 & 252.108 \\
\hline & Total & & $\mathbf{9 5 2 7 2 4}$
\end{tabular}

Initial Landuse Potential Map merupakan peta transisi setiap penggunaan lahan yang sudah dihasilkan pada analisis sebelumnya.

Constraint Landuse, yakni menunjukkan landuse yang memiliki batasan pengembangan, sehingga landuse tersebut tidak akan berubah dan tetap terkait dengan berkembangnya penggunaan lahan permukiman, industri, perdagangan dan jasa, tambak yang diprediksikan. Berikut Constraint Landuse setiap penggunaan lahan.

Tabel 4.

Landuse

\begin{tabular}{|c|c|c|}
\hline NO & LANDUSE & CONTRAINS LANDUSE \\
\hline 1 & Permukiman & $\begin{array}{l}\text { Fasilitas Umum, Industri } \\
\text { Pergudangan, Rencana OERR, Jalan, } \\
\text { Milite, Perdagangan dan Jasa, Sungai, } \\
\text { RTH }\end{array}$ \\
\hline 2 & Industri & $\begin{array}{l}\text { Fasilitas Umum, Rencana OERR, Jalan, } \\
\text { Militer, , Sungai, RTH }\end{array}$ \\
\hline 3 & $\begin{array}{l}\text { Perdagangan dan } \\
\text { Jasa }\end{array}$ & $\begin{array}{l}\text { Fasilitas Umum, } \\
\text { Pergudangan, Rencana } \\
\text { Militer, Sungai, RTH }\end{array}$ \\
\hline 4 & Tambak & $\begin{array}{l}\text { Fasilitas Umum, Industri dan } \\
\text { Pergudangan, Permukiman, Perdagangan } \\
\text { dan Jasa, Rencana OERR, Jalan, Militer, } \\
\text { Sungai, RTH }\end{array}$ \\
\hline
\end{tabular}

Hasil permodelan ini menghasilkan nilai akurasi sebesar $83,5 \%$. Sehingga dapat disimpulkan bahwa model memiliki tingkat akurasi yang diterima yaitu $80 \%$ (Easteman, 2012).

Hasil dari permodelan prediksi spasial prediksi perkembangan penggunaan lahan Pamurbaya pada tahun 2034 sebagai berikut.

- Perkembangan penggunaan lahan permukiman tahun 2034 mengalami kenaikan luasan sebanyak $64 \%$. Penambahan 
tersebut didapatkan dari konversi berbagai penggunaan lahan oleh permukiman diantaranya
- Tambak 511.801 sel
- Pertanian 83.333 sel
○ Lahan kosong $62.297 \mathrm{sel}$
○ Hutan mangrove 25.079 sel

- Perkembangan pernggunaan lahan industri tahun 2034 mengalami kenaikan luasan sebanyak $7 \%$. Penambahan tersebut didapatkan dari konversi berbagai pengggunaan lahan oleh industri yaitu permukiman sebanyak 2.647 sel.

- Perkembangan penggunaan lahan perdagangan dan jasa tahun 2034 mengalami kenaikan luasan sebanyak 15\%. Penambahan tersebut didapatkan dari konversi berbagi pengunaan lahan oleh perdagangan dan jasa diantaranya

\section{○ Tambak 37 sel \\ - Permukiman 11.134 sel \\ ○ Lahan kosong 105 sel}

Selain kenaikan luasan, ada beberapa penggunaan lahan pasif yang terkonversi secara signifikan bahkan hingga luasan penggunaan lahannya habis. Penggunaan lahan tambak mengalami konversi yang signifikan hingga luasnya berkurang sebesar 29\%. Hal tersebut juga dialami oleh penggunaan lahan hutan mangrove yang berada dibibir pantai, lahan kosong dan lahan pertanian yang habis luasannya. Diketahui lahan kosong akan habis pada tahun 2024 dan pertanian akan habis pada tahun 2025. Sedangkan mangrove dibibir sungai akan habis pada 2034.

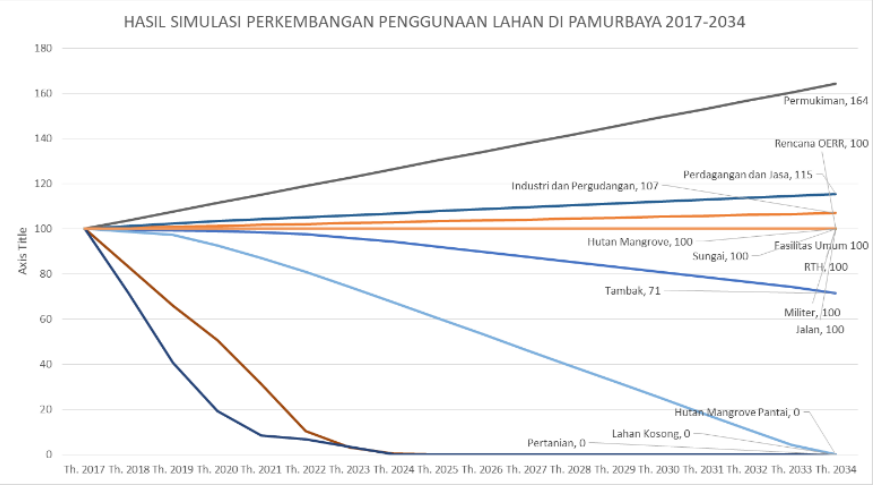

Gambar 11. Grafik Hasil Simulasi Perkembangan Penggunaan lahan Pamurbaya 2017-2034
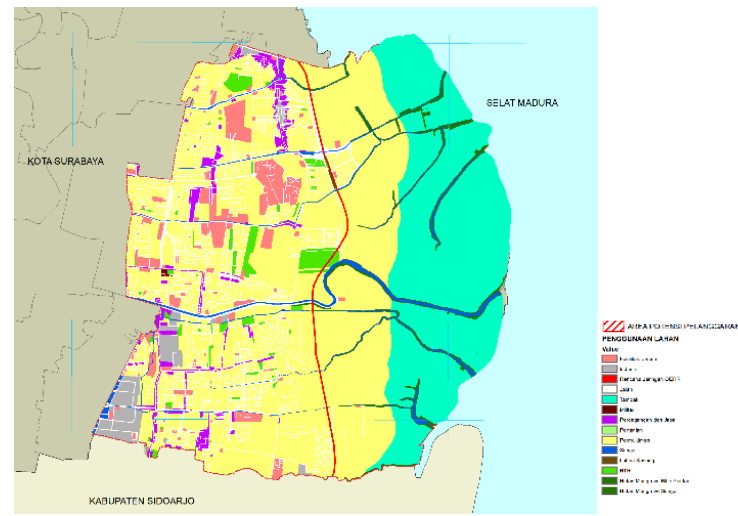

Gambar 12. Peta Hasil Simulasi Perkembangan Lahan Pamurbaya pada Tahun 2034
D. Mengidentifikasi Potensi Pelanggaran Kawasan Konservasi Pamurbaya Tahun 2034

Hasil yang didapakan menyatakan bahwa pada tahun 2019 potensi pelanggaran yang terjadi sangat kecil yaitu seluas 13.63 Ha. Kemudian pada tahun 2024 terjadi kenaikan yang tidak signifikan, potensi pelanggaran naik menjadi 21.23 Ha. Pada tahun 2029 terjadi kenaikan signifikan pada potensi pelanggaran di kawasan konservasi Pamurbaya menjadi 226..57 Ha. Kemudian kenaikan signifikan terjadi lagi pada tahun 2034, naik menjadi $622.67 \mathrm{Ha}$. Hal ini menunjukan kurva yang eksponesial, karena disebabkan oleh arah permodelan prediksi tren perkembangan lahan. Untuk lebih detailnya dapat di lihat pada grafik di bawah.

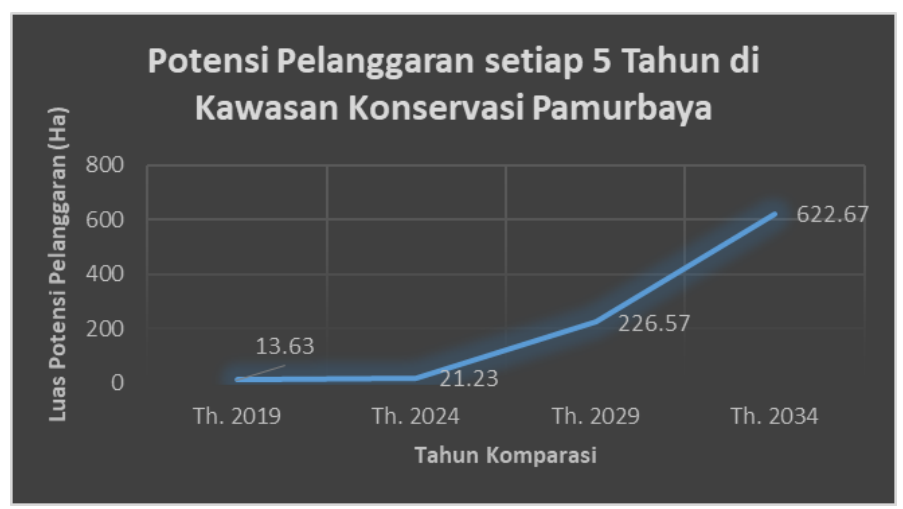

Gambar 13. Grafik Potensi Pelanggaran setiap 5 tahun Pamurbaya

Jika ditinjau dari sudut pandang per Kecamatan, pada tahun 2019 dan 2024 potensi pelanggaran di setiap Kecamatan hampir sama, karena sangat kecil potensi pelanggaran yang terjadi. Akan tetapi di tahun 2029 mulai terjadi perbedaan luas potensi pelanggaran di setiap Kecamatan di Pamurbaya. Paling besar luasannya adalah Kecamatan Sukolilo dan Rungkut. Kemudian di tahun 2034 luas potensi pelanggaran naik secara linier dengan Kecamatan Sukolilo paling besar. Untuk lebih detail dapat dilihat pada grafik di bawah.

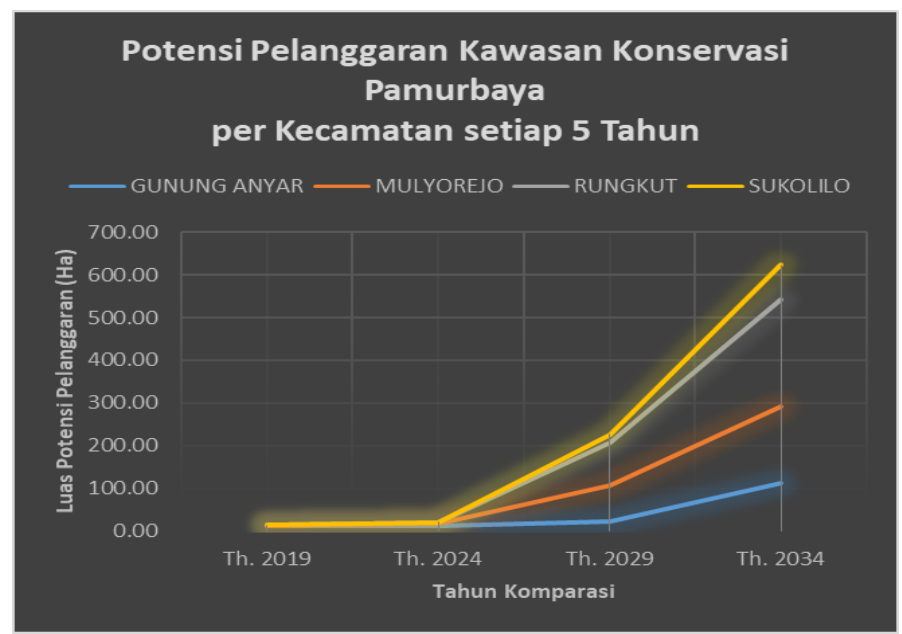

Gambar 14. Grafik Potensi Pelanggaran Kawasan Konservasi Pamurbaya per Kecamatan setip 5 Tahun

Berikut detail dari hasil prediksi potensi pelanggaran kawasan konservasi berdasarkan model perubahan penggunaan lahan. 
- Pada tahun 2019 potensi pelanggaran diprediksi akan terjadi sangat minim hanya sebesar $0,53 \%$ atau dari 2.592,31 kawasan konservasi Pamurbaya yang berpotensi hilang adalah seluas 13,63 Ha.

- Pada tahun 2024 potensi pelanggaran diprediski akan terjadi sangat minim hanya sebesar $0,82 \%$ atau dari 2.592,31 kawasan konservasi Pamurbaya yang berpotensi hilang adalah seluas $21,23 \mathrm{Ha}$.

- Pada tahun 2029 potensi pelanggaran diprediski akan terjadi sangat minim hanya sebesar $8,74 \%$ atau dari 2.592,31 kawasan konservasi Pamurbaya yang berpotensi hilang adalah seluas 226,57 Ha.

- Pada tahun 2034 potensi pelanggaran diprediski akan terjadi sangat minim hanya sebesar $24,02 \%$ atau dari 2.592,31 kawasan konservasi Pamurbaya yang berpotensi hilang adalah seluas 622,67 Ha.
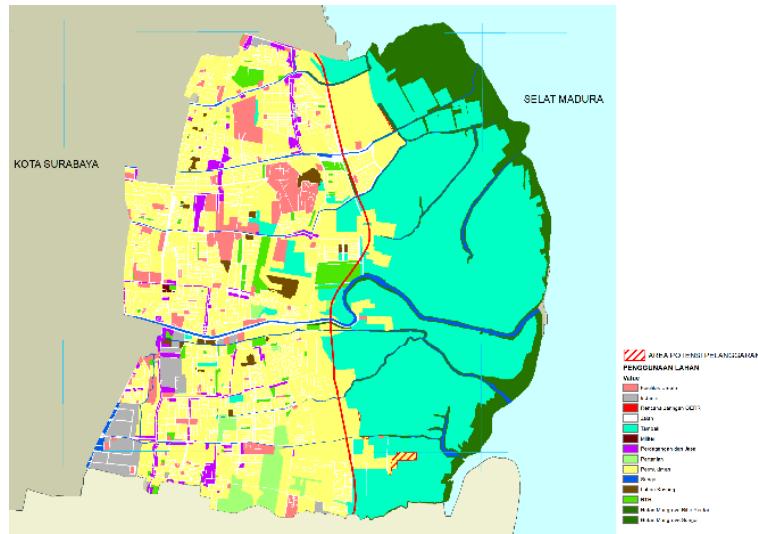

Gambar 15. Peta Potensi Pelanggaran pada Tahun 2019

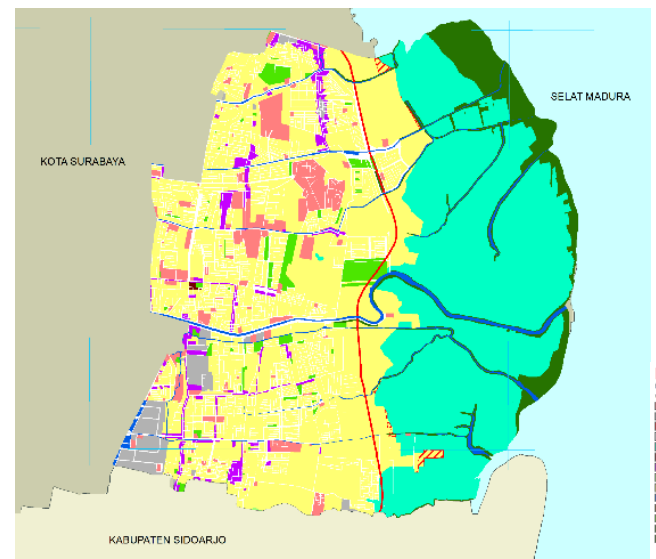

Gambar 16. Peta Potensi Pelanggaran pada Tahun 2014
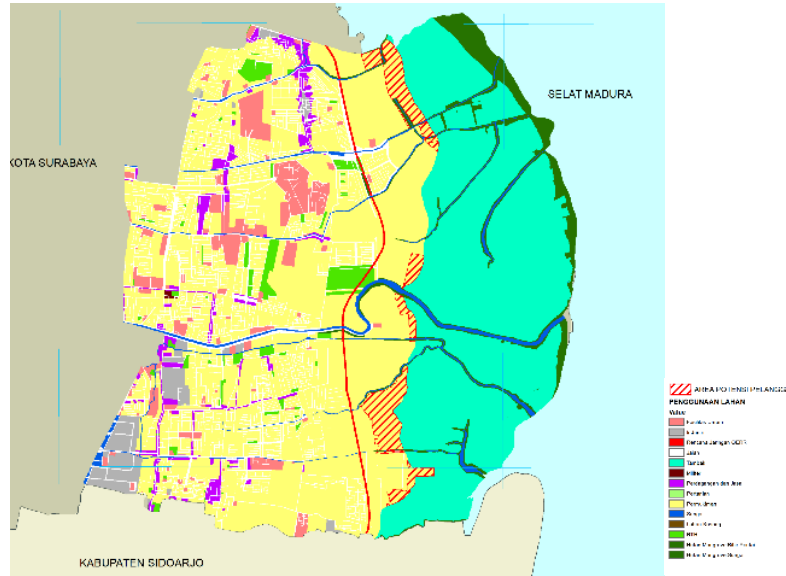

Gambar 17. Peta Potensi Pelanggaran pada Tahun 2020

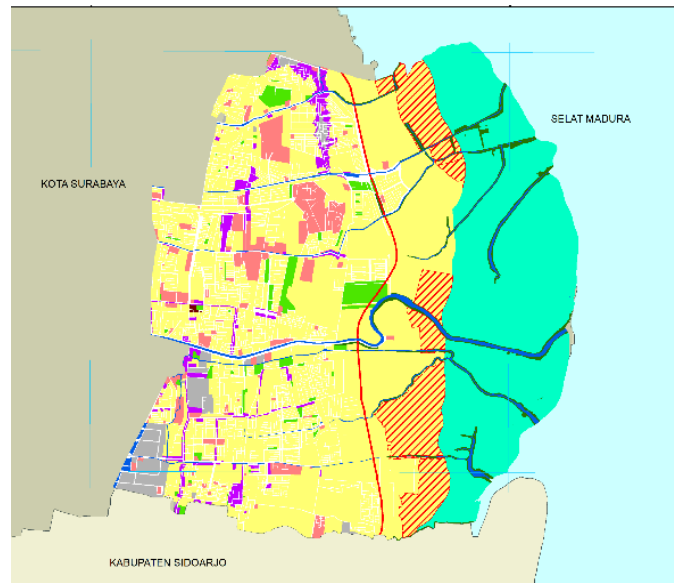

Gambar 18. Peta Potensi Pelanggaran pada Tahun 2034

\section{KESIMPULAN DAN SARAN}

Berdasarkan hasil simulasi perkembangan penggunaan lahan Pamurbaya pada tahun 2034 diketahui bahwa perkembangan lahan terbangun mengarah kearah timur sejauh maksimal 738 meter mendekati arah pantai. Juga didapatkan bahwa permukiman selama 17 tahun kedepan diprediksi tumbuh hingga $64 \%$, industri diprediksi tumbuh $7 \%$, perdagangan dan jasa diprediksi tumbuh hingga $15 \%$. Selain itu, juga terjadi berkurangnya penggunaan lahan tambak sebanyak $29 \%$ dan lahan kosong serta hutan mangrove di bibir pantai akan hilang pada tahun 2024-2025.

Hasil identifikasi potensi pelanggaran kawasan konservasi Pamurbaya berdasarkan hasil model spasial prediksi perkembangan penggunaan lahan tahun 2034 diketahui pada tahun 2019 diprediksi kawasan konservasi akan hilang sebanyak $0,53 \%$, tahun 2024 akan hilang sebanyak $0,82 \%$, tahun 2029 akan hilang sebanyak $8,7 \%$ dan pada tahun 2034 akan hilang sebanyak $24,02 \%$.

Hasil dari penelitian ini dapat dijadikan sebagai referensi untuk Pemerintah Kota Surabaya untuk menyusunkan dokumen tata ruang terkait. Saran dari penelitian ini adalah karena penelitian ini mengasumsikan bahwa garis pantai tidak berubah, maka penelitian lanjutannya diharapkan dapat mengakomodasi perubahan garis pantai. Selain itu juga perlu dilakukan kajian pada daerah yang di plot memiliki potensi pelanggaran untuk 
diadakan kajian apakah tetap akan dipertahankan sebagai kawasan lindung, atau diputihkan menjadi lahan budidaya.

\section{DAFTAR PUSTAKA}

Anonim. (2006). Makalah Lokakarya IPB tentang Pengembangan Sistem RTH di Perkotaan.

Anonim. (2009, Oktober 29). Retrieved from Konservasi Alam: http://gangcemara.blogspot.com/2007/09/ko

Arief, M. (2011). Kajian Perubahan Garis Pantai Menggunakan Data Satelit Landsat Di Kabupaten Kendal. Jurnal Penginderaan Jauh Vol. 8, 71-80.

Arsyad, S. (1989). Konservasi Tanah dan Air. Bogor: IPB.

Direktorat Jenderal Perikanan . (2001). Konversi Mangrove Menjadi Tambak.

Easteman, J. (2012). IDRISI Manual. Worcester: IDRISI Production. Fidelis, A. (2017). Analisa Kesesuaian Lahan Untuk Lokasi Pengembangan Permukiman Menggunakan Metode Scoring (Studi Kasus: Surabaya Timur). Tugas Akhir Jurusan Teknik GeomatikaITS.

Fitiani. (2013). Analisis Deviasi Pemanfaatan Ruang Aktual Terhadap Rencana Detil Tata Ruang Kota (RDTRK) Kecamatan Ngaglik Tahun 2009-2018. Publikasi Karya Ilmiah.

Harjanti, A. d. (2002). Identifikasi Faktor-Faktor Penyebab Perubahan Penggunaan Lahan Permukiman Menjadi Komersial di Kawasan Kemang Jakarta Seatan. Jakarta: Universitas Diponegoro. Haryani, P. (2011). Perubahan Penutupan/Penggunaan Lahan Dan Perubahan Garis Pantai Di Das Cipunagara Dan Sekitarnya, Jawa Barat. Tugas Akhir Fakultas Pertanian IPB.

Michico, N. R. (2017, Juli 8). Risma: Lingkungan Dikelola, Ekonomi Makin Baik. Retrieved from Detik News: https://news.detik.com/berita/d-3552843/risma-lingkungan-dikelolaekonomi-makin-baik/komentar

Mulyadi, E. (2012). KONSERVASI HUTAN MANGROVE SEBAGAI EKOWISATA. Ilmiah Teknik Lingkungan Vol.2 No. 1, 11-18.

Nadlir, M. (2017, Juli 18). RI Akan Implementasikan 169 Agenda Sustainable Development Goals. Retrieved from Kompas Ekonomi: https://ekonomi.kompas.com/read/2017/07/18/212201626/ri-akanimplementasikan-169-agenda-sustainable-development-goalsNovianty, R. (2009). Identifikasi Kerusakan Dan Upaya Rehabilitasi Ekosistem Mangrove Di Pantai Utara Kabupaten Subang.

Nugroho, P. (2009). Studi Kebijakan Pembangunan Terhadap Perubahan Tata Ruang Di Kota Semarang. Riptek, 41-51.

Pratomoatmojo, N. A. (2012). Land Use Change Modelling Under Tidal Flood Scenario By Means Of Markov-Cellular Automata In Pekalongan Municipal. Yogyakarta: Universitas Gadjah Mada.

Pratomoatmojo, N. A. (2014). LanduseSim sebagai aplikasi pemodelan dan simulasi spasial perubahan penggunaan lahan berbasis Sistem Informasi Geografis dalam konteks perencanaan wilayah dan kota. Cities.

Purwoko, A. (2005). Dampak Kerusakan Ekosistem Hutan Bakau (Mangrove) Terhadap Pendapatan Masyarakat Pantai Di Kecamatan Secanggang, Kabupaten Langkat. e-USU Repository Universitas Sumatera Utara .

Rachmatullah, T. (2016). Tingkat Deviasi Konversi Lahan di Kawasan Lindung Kelurahan Wonorejo Surabaya. JURNAL TEKNIK ITS, 5.

Rahwamati, D. (2014). Mangrove Conservation Area in Wonorejo. Presentasi CommTech ITS : Strands Of Sands Surabaya.

Ritohardoyo, S. (2011). Arahan Kebijakan Pengelolaan Hutan Mangrove: Kasus Pesisir Kecamatan Teluk Pakedai, Kabupaten Kubu Raya,Propinsi Kalimantan Barat. Jurnal Geografi Vol 8 No. 2. Ruslisan, d. (2015). Prediksi Perubahan Penggunaan Lahan Terbangun Terhadap Kesesuaian Rancangan Tata Ruang Wilayah
Menggunakan Regresi Berdasar Data Spasial dan PenginderaanJauh di Kota Semarang. Conference on URBAN STUDIES AND DEVELOPMENT.

Subroto, G. (2016). Pemodelan Spasial Alokasi Peruntukan Lahan Pertanian Pangan Berkelanjutan di Kabupaten Jombang Jawa Timur. Surabaya: Tugas Akhir.

SurabayaPost. (2013, Maret 03). 70\% Lingkar Timur Dikuasai Pengembang. Retrieved from Surabaya Post: https://www.facebook.com/permalink.php?id=290135727760550\&s tory_fbid=514222981957919

Susilo, B. (2011). Pemodelan Spasial Probabilistik Integrasi Markov Chain Dan Cellular Automatauntuk Kajian Perubahan Penggunaan Lahan Skala Regional Di Provinsi Daerah Istimewa Yogyakarta. Gea. Toyyibuloh, Y. (2012). Evaluasi Rencana Tata Ruang Wilayah Berdasarkan Indeks Potensi Lahan Melalui Sistem Informasi Geografis Di Kabupaten Sragen . Publikasi Karya Ilmiah Universitas Muhammadiyah Surakarta.

Undang-Undang No. 26 Tahun. (2007). Tentang Penataan Ruang. Jakarta.

Vreugdenhil, C. B. (1999). Transport Problems in Shallow Water, Battle-neeks and Appropriate Modeling. Seminar on Sediment Transport Modelling.

Wati, M. W. (2016). Strategi Pengelolaan Ekowisata Mangrove Wonorejo Berdasarkan Preferensi Stakeholders. Tugas Akhir Sarjana PWK-ITS.

Wijaya, A. (2017). Analisis Dinamika Pola Spasial Penggunaan Lahan Pada Wilayah Terdampak Kenaikan Muka Air Laut di Kota Pekalongan. POMITS.

Wijayanti, T. (2011). Konservasi Hutan Mangrove Sebagai Wisata Pendidikan . Tri Wijayanti.

Zaky, A. R. (2012). Kajian Kondisi Lahan Mangrove di Desa Bedono, Kecamatan Sayung, Kabupaten Demak dan Kelurahan Mangunharjo, Kecamatan Tugu, Kota Semarang . Journal Of Marine Research, 1, 88-97. 